\title{
Eksplorasi Etnomatematika pada Bangunan Candi Jabung di Desa Jabung Probolinggo sebagai Bahan Ajar Siswa
}

\author{
Author: \\ Mohamad Yasin Fadillah ${ }^{1}$ \\ Sunardi ${ }^{2}$ \\ Toto' Bara Setiawan ${ }^{3}$ \\ Nida'an Chofiyyah Astari ${ }^{4}$
}

\author{
Affiliation: \\ ${ }^{1,2,3}$ University of Jember, East \\ Java, Indonesia \\ ${ }^{4}$ MTs Al-Islamiyah Lumajang, \\ East Java, Indonesia
}

Corresponding author:

Mohamad Yasin Fadillah,

myfadil45@gmail.com

\section{Dates:}

Received: 27/2/2021

Accepted: 12/3/2021

Published: 16/3/2021

\begin{abstract}
Abstrak. Etnomatematika adalah matematika yang dipraktikkan oleh kelompok budaya, seperti masyarakat pedesaan dan perkotaan dalam melaksanakan kegiatan budaya tertentu. Kebudayaan dapat berupa karya berupa bangunan yang memiliki ciri khas tertentu. Penerapan matematika dengan budaya akan memudahkan siswa dalam proses pembelajaran. Penelitian ini bertujuan untuk mengetahui etnomatematika Candi Jabung di Desa Jabung Probolinggo dan sebagai bahan pembuatan paket tes siswa berupa soal. Jenis penelitian ini adalah penelitian kualitatif dengan pendekatan etnografi. Metode pengumpulan data yang digunakan adalah observasi dan wawancara. Hasil penelitian menunjukkan bahwa terdapat konsep matematika pada Candi Jabung yang meliputi persegi panjang, segitiga, lingkaran, belah ketupat, tabung, balok, kesamaan, kesesuaian, terjemahan, refleksi, dilatasi. Hasil penelitian ini berupa paket tes siswa kelas IX SMP / MTs. yang berisi etnomatematika di Candi Jabung.
\end{abstract}

Kata kunci: etnomatematika, candi Jabung, paket tes

\begin{abstract}
Ethnomatematics is mathematics that is practiced by cultural groups, such as rural and urban communities in carrying out certain cultural activities. Culture can be in the form of works such as buildings that have certain characteristics. Mathematics with the application of culture will make it easier for students in the learning process. This study aims to determine the ethnomatematics of Jabung temple in Jabung village, Probolinggo and as a material for making student test packages in the form of questions. This type of research is qualitative research with an ethnographic approach. Data collection methods used were observation and interviews. This study shows that there are mathematical concepts in the Jabung temple including rectangle, triangle, circle, rhombus, tube, beam, similarity, congruence, translation, reflection, dilatation. The results of this study were student test packages for class IX SMP / MTs. which contains ethnomatematics in Jabung temple.
\end{abstract}

Keywords: ethnomatematics, jabung temple, test packages

\section{Jo M}

This work is licensed under a Creative Commons Attribution-ShareAlike 4.0 International License.

Read online:

https://jurnal.unej.ac.id/index.php/JOMEAL/index or scan barcode beside.

How to cite this article:

Fadillah, M., Sunardi, S., Setiawan, T., \& Astari, N. (2021). Eksplorasi Etnomatematika pada Bangunan Candi Jabung di Desa Jabung Probolinggo sebagai Bahan Ajar Siswa. Journal of Mathematics Education and Learning, 1(1), 83-91. Retrieved from https://jurnal.unej.ac.id/index.php/JOMEAL/article/view/24378 


\section{Pendahuluan}

Matematika adalah ilmu yang mendasari ilmu lainnya. Menurut Fataturrohmah (dalam Fataturrohmah,2017), matematika merupakan ilmu pengetahuan yang tersusun secara sistematis dari konsep yang paling sederhana hingga konsep yang sangat kompleks. Matematika memiliki 6 cabang ilmu yaitu Aljabar, Aritmatika, Trigonometri, Kalkulus, dan Geometri (Ngiza, 2015). Penggunaan matematika hampir di setiap aspek kehidupan, salah satunya dalam aspek kebudayaan.

Liliweri (dalam Liliweri, 2006) menyatakan bahwa kebudayaan merupakan pandangan hidup dari sekelompok orang dalam bentuk kepercayaan, perilaku, nilai, dan simbol-simbol yang semuanya diterima tanpa sadar dan diwariskan melalui komunikasi dari satu generasi ke generasi. Budaya melandasi perilaku masyarakat, karena budaya merupakan pengetahuan manusia yang digunakan untuk memahami lingkungan serta pengalaman yang terjadi kepada manusia itu sendiri (Suparlan, 1999). Koentjaraningrat menyebutkan paling sedikit terdapat tiga wujud kebudayaan, salah satunya adalah benda-benda hasil karya manusia (Koentjaraningrat, 1974). Benda hasil karya manusia yang tergolong kebudayaan adalah benda-benda yang memiliki ciri khusus, salah satunya adalah bangunan. Hal tersebut tidak menutup kemungkinan adanya konsep matematika didalamnya.

Konsep matematika yang terkandung pada budaya dibahas dalam etnomatematika. Etnomatematika digunakan untuk menunjukkan matematika yang terdapat dalam lingkugan masyarakat berkaitan dengan latar belakang sosial, ekonomi, dan budaya suatu masyarakat (Safitri, 2015). Salah satu budaya yang terdapat pada lingkungan masyarakat adalah bangunan. Bangunan memiliki berbagai macam jenis, salah satunya adalah candi. Menurut Hardiati (dalam Hardiarti dkk, 2017) candi adalah peninggalan arsitektural yang berasal dari masa klasik indonesia yaitu masa berkembangnya kebudayaan yang berlatar belakang agama Hindu dan Budha, dari abad ke-5M sampai ke-15M (Hardiarti, Sylviyani, 2017). Pada daerah Probolinggo terdapat suatu candi peninggalan kerajaan Majapahit yaitu candi Jabung, tepatnya berada di desa Jabung, Probolinggo. Candi Jabung memiliki relief-relief pada permukaannya, serta bentuk-bentuk menonjol yang terdapat pada setiap bagian candi.

Konsep matematika pada candi Jabung kemudian dijadikan sebagai bahan untuk membuat bahan ajar siswa yaitu paket tes berbentuk soal. Menurut Suharsimi Arikunto yang dimaksud dengan tes adalah alat atau prosedur yang digunakan untuk mengetahui atau mengukur sesuatu dalam suasana, dengan cara dan aturan-aturan yang sudah ditentukan adalah panduan bagi siswa dalam memahami keterampilan proses dan konsep-konsep materi yang sedang dan akan dipelajari (Arikunto, 2006).

Pada penelitian ini dibahas mengenai etnomatematika pada candi Jabung terkait dengan konsep matematika. Hasil dari penelitian ini digunakan sebagai bahan pembuatan paket tes berbentuk soal dengan pokok bahasan transformasi geometri untuk kelas IX SMP/MTs.

\section{Metode Penelitian}

Pada penelitian ini metode yang digunakan adalah kualitatif dengan pendekatan etnografi. Penelitian dilakukan di desa Jabung, Probolinggo. Objek yang diteliti adalah candi Jabung dengan melihat konsep matematika yang terdapat pada bagian-bagian candi dan relief-relief pada permukaannya.

Terdapat beberapa langkah yang dilakukan dalam proses penelitian. Langkah pertama yaitu pendahuluan. Pada tahap ini dilaksanakan observasi awal pada beberapa bangunan candi untuk menentukan topik permasalahan yang dijadikan objek penelitian, dan dipilihlah candi Jabung sebagai 
objek penelitian. Candi Jabung dipilih karena bangunannya masih terlihat kokoh, serta konsep matematika pada candi tersebut lebih banyak daripada candi lain yang telah diamati. Langkah kedua adalah membuat instrumen penelitian sebagai pedoman yang akan digunakan saat observasi dan wawancara. Langkah selanjutnya yaitu validasi instrumen, hal yang dilakukan adalah memberikan pedoman observasi, pedoman wawancara, dan lembar validasi instrumen kepada dua dosen pendidikan matematika sebagai validator. Pedoman dinyatakan valid apabila nilai $V_{a} \geq 0,5$. Hasil validasi menunjukkan pedoman observasi bernilai 0,88 , dan pedoman wawancara bernilai 0,94 yang berarti kedua pedoman dinyatakan valid. Pedoman observasi dan pedoman wawancara yang telah dinyatakan valid sudah dapat digunakan saat melakukan penelitian. Langkah keempat yaitu pengumpulan data yang dilakukan dengan cara observasi dan wawancara yang bertujuan untuk menggali konsep-konsep pada bangunan candi. Wawancara dilakukan pada subjek penelitian untuk memperkuat dan mendukung data yang telah didapatkan pada saat observasi. Subjek penelitian terdiri dari 2 orang yaitu juru kunci candi, dan tukang bangunan. Langkah kelima yaitu melakukan analisis data, dimana data yang telah diperoleh dari observasi dan wawancara dianalisis etnomatematikanya yang ada pada candi Jabung. Selanjutnya hasil analisis data dibuat sebagai bahan paket tes berbentuk soal yang berkaitan dengan etnomatematika pada candi Jabung. Paket tes tersebut kemudian divalidasi oleh validator. Langkah ketujuh pada penelitian ini adalah menarik kesimpulan.

\section{Hasil dan Pembahasan}

Candi Jabung merupakan salah satu candi peningalan kerajaan Majapahit yang bertempat di desa Jabung, Probolinggo. Terdapat empat bgaian pada candi Jabung, antara lain atap candi, badan candi, kaki candi tingkat 1 , dan kaki candi tingkat 2. Observasi dilakukan oleh dua orang observer dengan kode P1 dan P2. Wawancara dilakukan pada dua subjek yaitu juru kunci candi, dan tukang bangunan dengan kode S3 dan S4. Berdasarkan hasil observasi dan wawancara dari kedua subjek penelitian, terdapat etnomatematika pada motif roster bangunan diantaranya bangun datar, bangun ruang, transformasi geometri, kesebangunan, dan kekongruenan.

\section{A. Bangun Datar}

Konsep bangun datar pada candi Jabung terdapat pada relief dan beberapa bentuk pada bagian candi. Cuplikan pertanyaan dan jawaban dengan juru kunci candi Jabung mengenai konsep bangun datar pada relief candi, sebagai berikut.

P1012 Dibagian atap itu ada bentuk apa ya pak?

S1012 Itu bentuknya seperti belah ketupat itu mas, tapi itu cuma motif hias, ini semua ukurannya sama karena ini ada disetiap pojoknya mas.

P1023 Kalau bentuk pintunya sendiri itu apa ya pak?

S1023 Kalau bentuk pintu sama yang seperti jendela itu persegi panjang mbak.

Pada setiap bagian candi terdapat konsep bangun datar. Konsep tersebut didapat dari bentukbentuk pada bangunan candi serta relief-relief di permukaan cadi. Beberapa konsep bangun datar pada candi Jabung disajikan pada Tabel 1 berikut. 
Tabel 1. Konsep Bangun Datar pada Candi Jabung

\begin{tabular}{|l|l|}
\hline Roster & \multicolumn{1}{|c|}{ Keterangan } \\
\hline & $\begin{array}{l}\text { Relief tersebut berbentuk belah ketupat yang } \\
\text { terdapat pada badan candi }\end{array}$ \\
\hline
\end{tabular}

\section{B. Bangun Ruang}

Konsep bangun ruang pada candi Jabung diperoleh dari bentuk bangunan secara keseluruhan pada beberapa bagian candi. Cuplikan pertanyaan dan jawaban dengan juru kunci candi Jabung mengenai konsep bangun ruang, sebagai berikut.

P1006 Kalau candi Jabung sendiri secara keseluruhan itu berbetuk apa ya pak?

S1006 Bentuknya seperti silinder yang bagian atas soalnya dalam bukunya silinder bentuknya. Kalau yang bawah persegi panjang atau kotak mas.

Wawancara tersebut menjelaskan bahwa terdapat konsep bangun ruang pada candi Jabung yaitu pada bentuk badan candi dan kaki candi. Dijelaskan bahwa badan candi berbentuk tabung, sedangkan kaki candi berbentuk kotak yang berarti balok. Beberapa konsep bangun ruang pada candi Jabung disajikan pada Tabel 2 berikut.

Tabel 2. Konsep Bangun Ruang pada Candi Jabung

\begin{tabular}{|c|l|}
\hline Roster & \multicolumn{1}{|c|}{ Keterangan } \\
\hline & $\begin{array}{l}\text { Bagian badan candi berbentuk } \\
\text { tabung }\end{array}$ \\
\hline & \\
\hline & Kaki candi berbentuk balok \\
\hline & \\
\hline
\end{tabular}




\begin{tabular}{|c|c|}
\hline Roster & Keterangan \\
\hline & \\
\hline
\end{tabular}

\section{Kesebangunan dan Kekongruenan}

Konsep kesebangunan dan kekongruenan terdapat pada relief dan beberapa bentuk pada bagian candi Jabung. Konsep kekongruenan didapat dari relief-relief serta bangun pada candi yang memiliki bentuk dan ukuran yang sama. Konsep kesebangunan didapat dari relief dan bagian candi dengan bentuk sama tetapi memiliki ukuran berbeda. Cuplikan pertanyaan dan jawaban dengan tukang bangunan terkait konsep kesebangunan pada candi Jabung, sebagai berikut.

P2017 Baik, bapak. Beralih ke bagian kepala ya Pak. Untuk bagian kepalanya itu yang tengah ada bentuk apa ya, Pak?

S2017 Kalau tengah itu ada dua baris ya mas, atas sama bawah. Reliefnya itu ada lima dengan bentuk sama. Kalau dilihat, bagian bawah itu lebih besar dari pada yang atas.

Pada wawancara tersebut menjelaskan bahwa terdapat relief-reief pada bagian atap candi dengan bentuk yang sama tetapi memiliki ukuran lebih besar pada relief bagian bawahnya. Cuplikan pertanyaan dan jawaban dengan tukang bangunan mengenai konsep kekongruenan pada candi Jabung, sebagai berikut.

P2009 Baik bapak. Di bagian badan yang bawah itu ada relief bentuk apa ya, Pak?

S2009 Di tengah itu ada dua relief bentuk persegi panjang, mas. Ukurannya sama dan ditaruh pas di tengah.

Wawancara tersebut menjelaskan terdapat konsep kekongruenan pada dua relief dimana memiliki bentuk dan ukuran yang sama. Beberapa konsep kesebangunan dan kekongruenan pada roster bangunan disajikan pada Tabel 3 berikut.

Tabel 3. Konsep Kesebangunan dan Kekongruenan pada Candi Jabung

\begin{tabular}{|l|l|}
\hline Roster & \multicolumn{1}{|c|}{ Keterangan } \\
\hline & $\begin{array}{l}\text { Terdapat relief sebanyak 3 baris, dengan bentuk yang sama } \\
\text { tetapi ukurannya lebih besar pada baris bawahnya. }\end{array}$ \\
\hline
\end{tabular}




\begin{tabular}{|c|l|}
\hline Roster & \multicolumn{1}{|c|}{ Keterangan } \\
\hline $0-0$ & $\begin{array}{l}\text { Dua relief lingkaran pada kaki tingkat 2 memiliki ukuran yang } \\
\text { sama }\end{array}$ \\
\hline
\end{tabular}

\section{Transformasi Geometri}

Terdapat beberapa konsep transformasi geometri yang diperoleh dari bagian-bagian candi dan relief-relief candi, antara lain konsep translasi, dilatasi, dan refleksi.

1) Translasi

Terdapat konsep translasi pada relief-relief candi dan beberapa bagian candi. Konsep translasi dihasilkan dari relief-relief serta bagian candi yang memiliki bentuk dan ukuran yang sama, dimana antara bentuk satu dan yang lain memiliki jarak. Cuplikan pertanyaan dan jawaban dengan tukang bangunan terkait konsep translasi, sebagai berikut.

P2005 Lalu di bagian tengah kaki itu ada reief berjajar berbentuk apa ya pak?

S2005 Itu bentukya lingkaran mas.

Wawancara tersebut menjelaskan bahwa terdapat relief yang kongruen dan tersusun secara berjajar. Beberapa relief dan bagian candi yang memiliki konsep translasi disajikan pada Tabel 4 berikut.

Tabel 4. Konsep Translasi pada Candi Jabung

\begin{tabular}{|c|l|}
\hline Roster & \multicolumn{1}{|c|}{ Keterangan } \\
\hline & Relief lingkaran yang berukuran sama tersusun berjajar \\
\hline & $\begin{array}{l}\text { Bagian pembatas lantai candi berbentuk limas segitiga } \\
\text { tersusun berjajar }\end{array}$ \\
\hline
\end{tabular}

2) Dilatasi

Terdapat konsep dilatasi pada candi Jabung. Konsep dilatasi terdapat pada relief dan bagian candi memiliki bentuk sama tetapi ukurannya diperbesar atau diperkecil. Cuplikan pertanyaan dan jawaban dengan juru kunci candi terkait konsep dilatasi pada candi Jabung, sebagai berikut.

P1013 Ini pak bagian atap yang diatas, ini kan ada relief yang kecil kecil yang ada 5 itu bentuknya apa ya pak?

S1013 Itu bentuknya seperti candi candi kecil, terus itu ukuran kelimanya sama semua mbak. Tapi ukuran baris bawahnya lebih besar. 
Wawancara tersebut menjelaskan bahwa terdapat relief candi dengan bentuk yang sama tetapi ukurannya lebih besar pada relief baris bawahnya. Konsep dilatasi pada beberapa roster dijelaskan pada Tabel 5 berikut.

Tabel 5. Konsep Dilatasi pada Candi Jabung

\begin{tabular}{|l|l|}
\hline Roster & \multicolumn{1}{|c|}{ Keterangan } \\
\hline & $\begin{array}{l}\text { Terdapat 2 baris relief berbentuk sama, dengan ukuran } \\
\text { relief yang bawah lebih besar }\end{array}$ \\
\hline
\end{tabular}

3)

\section{Refleksi}

Pada hasil observasi terdapat konsep refleksi pada hampir semua bagian candi. Konsep refleksi rata-rata didapat dari permukaan secara keseluruhan tiap bagian pada candi. Bagian candi yang memiliki konsep refleksi adalah bagian atap, badan, dan kaki candi, dimana jika dibagi dua daerah sama besar secara vertical maka akan memiliki bentuk-bentuk bersesuaian yang sama. Cuplikan pertanyaan dan jawaban dengan tukang bangunan terkait konsep refleksi pada candi Jabung, sebagai berikut.

P2018 Oh enggeh, Bapak. Kalau dilihat dari satu sisi full apakah kalau dibagi dua ini bisa jadi sama persis ya, pak?

S2018 Iya mas. Kanan kiri sama, karena ini bentuknya simetris antara kanan dan kirinya.

P2023 Baik, bapak. Kalau bagian tugu kanan kiri ini apa sam persis ya bentuknya, pak?

S2023 Iya mbak, kalau tugunya ini antara kanan dan kiri bentuknya sama sampai yang bawahnya pintu itu

Wawancara tersebut menjelaskan bahwa terdapat bagian candi yang memiliki konsep refleksi dengan garis cermin vertical yang membagi dua daerah sama besar.

Beberapa bagian candi yang memiliki konsep refleksi disajikan pada Tabel 6.

Tabel 6. Konsep Refleksi pada Candi Jabung

\begin{tabular}{|l|l|}
\hline Roster & \multicolumn{1}{|c|}{ Keterangan } \\
\hline & $\begin{array}{l}\text { Bagian badan candi jika dibagi secara vertical dengan daerah } \\
\text { sama besar, maka akan menghasilkan bentuk-bentuk sama yang } \\
\text { bersesuaian }\end{array}$ \\
\hline
\end{tabular}




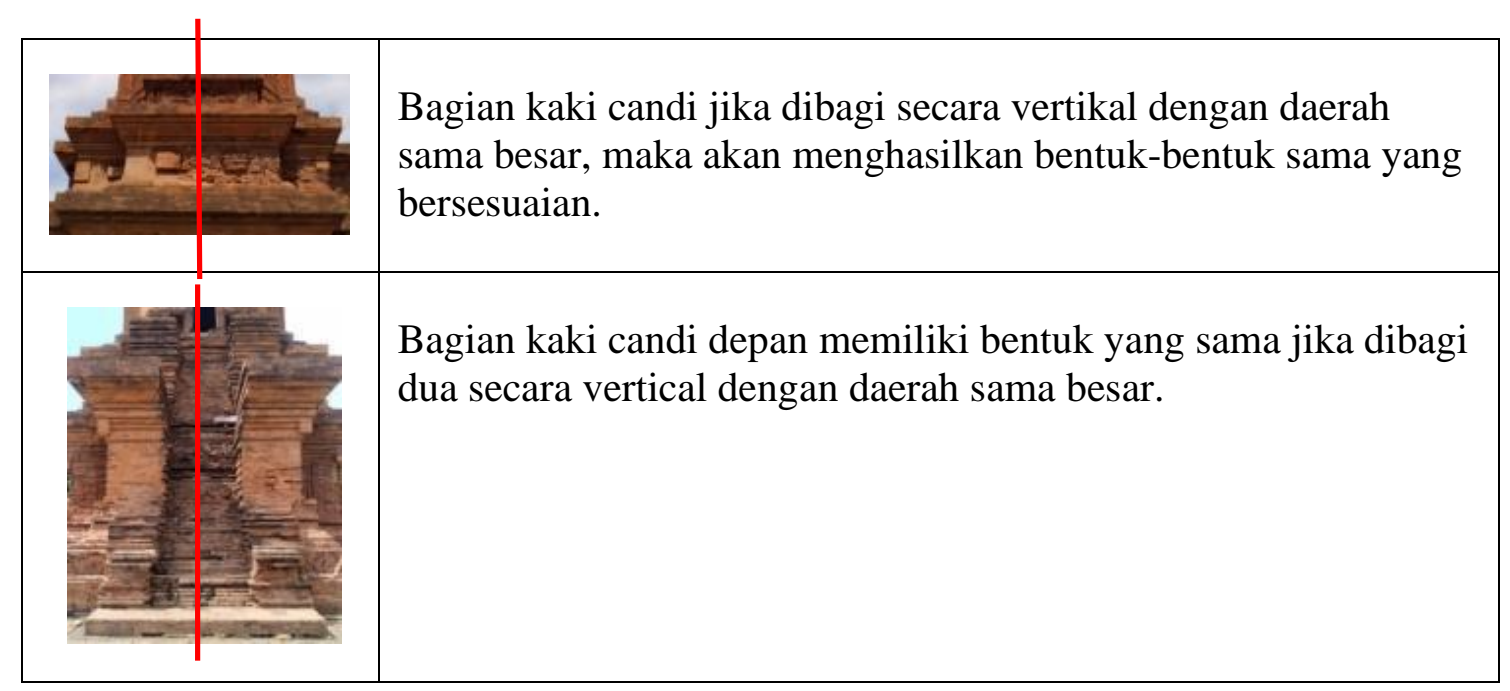

Etnomatematika pada candi Jabung yang tediri dari relief dan bagian-bagian candi yakni bangun datar, bangun ruang, transformasi geometri, kesebangunan, dan kekongruenan. Hasil peneltian ini dapat dikaitkan dengan penelitian yang dilakukan oleh Wahyuni (2018) pada Pura Mandara Giri, dimana terdapat unsur kesebangunan, bentuk geometris, serta transfomasi geometri pada bentuk bangunan maupun ukiran-ukiran yang terdapat pada pura. Penelitian lain yang dapat dikaitkan dengan penelitian ini adalah penelitian oleh Nurhasadah (2019) yang menunjukan terdapat konsep bangun datar dan bangun ruang pada candi Portibi. Konsep transformasi geometri yang didapat dari candi Jabung pada penelitian ini dijadikan sebagai bahan untuk membuat bahan ajar siswa berbentuk paket tes dengan pendekatan scientific.

Paket tes siswa yang dihaslkan berisi tentang soal-soal transformasi geometri yang meliputi translasi, refleksi, dan dilatasi berdasarkan hasil penelitian pada candi Jabung. Di dalamnya terdapat foto-foto candi Jabung yang memiliki konsep transformasi geometri. Paket tes transformasi geometri berdasarkan etnomatematika pada candi Jabung dapat diakses melalui tautan berikut. https://drive.google.com/file/d/1hx1g1JpuR4ss9v-hqGjysHuEz63egLSF/view?usp=sharing

\section{Kesimpulan}

Berdasarkan hasil dan pembahasan, terdapat beberapa etnomatematika pada candi Jabung. Etnomatematika yang didapat terdiri dari konsep bangun datar, bangun ruang, transformasi geometri, kesebangunan, dan kekongruenan. Konsep-konsep tersebut didapat pada bentuk relief dan bagianbagian candi. Konsep bangun datar yang dihasilkan anatara lain persegi, persegi panjang, segitiga, lingkaran, dan belah ketupat, dan trapesium. Konsep bangun ruang didapat dari bentuk bangunan candi pada bagian badan dan kaki candi, dimana badan candi berbentuk tabung, dan kaki candi berbebtuk balok. Konsep transformasi geometri yang didapat pada roster bangunan antara lain translasi, refleksi, dan dilatasi. Konsep translasi didapat dari relief-relief yang kongruen dengan penempatan disusun berjajar. Konsep refleksi didapat dari keseluruhan bentuk permukaan pada setiap bagian candi, dimana hasil refleksi memiliki bentuk sama yang bersesuaian dengan garis cermin vertikal. Konsep dilatasi didapat dari relief-relief dengan bentuk sama, tetapi ukurannya diperbesar, serta bagian candi dengan pinggirannya yang memiliki ukuran lebih besar. Konsep kekongruenan didapat dari relief-relief dengan bentuk dan ukuran yang sama. Konsep kesebangunan didapat dari 
bentuk pada bagian candi yang memiliki pinggiran dengan bentuk sama tetapi terdapat perbandingan pada ukurannya.

Etnomatematika yang terdapat pada roster bangunan selanjutnya digunakan sebagai bahan penyusunan paket tes siswa berbentuk soal. Paket tes siswa berisikan soal-soal transformasi geometri untuk kelas XI SMP/MTs. Paket tes tersebut berisi foto-foto roster sebagai objek pada soal mengenai konsep transformasi geometri.

\section{Daftar Pustaka}

Arikunto, S. (2006). "Prosedur Penelitian Suatu Pendekatan Praktik ", Jakarta : Rineka Cipta.

Fataturrohmah, A.,z dkk, "Pengaruh Model Cinta Berbantu Media Tangram Terhadap Pemahaman Konsep Matematis Siswa ", J. Seminar Nasional Matematika dan Pendidikan Matematika. vol. 1, no. 1, pp. 21-21. 2017

Hardiarti, Sylviyani. (2017). Etnomatematika: Aplikasi Bangun Datar Segiempat Pada Candi Muaro Jambi. Aksioma. 8(2):1-12.

Koentjaraningrat. (1974). "Pengantar Antropologi", Jakarta: Aksara Baru.

Liliweri, Alo. (2002). "Makna Budaya dalam Komuniaksi Antar Budaya", Bandung: PT LKIS Pelangi Aksara.

Ngiza. (2015). "Identifikasi Etnomatematika Petani Pada Masyarakat Jawa di Desa Sukoreno", http://www.ta.skripsi.ac.fj/D7625.dir/doc.pdf.

Nurhasadah. (2019). "Eksplorasi Etnomatematika Pada Bangunan Candi Portibi". Jurnal MathEducation Nusantara. 2(2):4-6.

Safitri, dkk. (2015). "Eksplorasi Konsep Matematika pada Permainan Masyarakat Melayu Sembas", J. Pontianak, Program Studi Pendidikan Matematika FKIP Untan.

Suparlan, P. (1999). Kemajemukan, Hipotesis Kebudayaan Dominan, dan Kesukubangsaan. Jurnal Antropologi Indonesia 22(56):13-20.

Wahyuni, S. (2018). Etnomatematika Pada Pura Mandara Giri Semeru Aung Sebagai Bahan Pembelajaran Matematika, Skripsi, Jember, Pendidikan Mateatika Universitas Jember. 